\title{
Effects of Catfish (Clarias gariepinus) Brood-stocks Egg Combination on Hatchability and Survival of Fish Larvae
}

\author{
Onada Olawale Ahmed ${ }^{1 *}$ and Ogunola Oluniyi Solomon ${ }^{2}$ \\ ${ }^{1}$ University of Ibadan, Nigeria \\ ${ }^{2}$ University of Bremen, Germany
}

\begin{abstract}
Fish seed production of catfish and tilapia has been successfully carried out in Nigeria. Despite the success, there still exist a wide gap between fish seed demand and supply, this therefore necessitate increased research for development. This project is aimed to study the effects of Clarias gariepinus brood-stocks' egg combination on hatchability and survival of fish larvae.

2 females gravid Clarias gariepinus brood stock size $(800-900 \mathrm{~g})$ were injected with pituitary gland hormone at 3 $\mathrm{mg} \mathrm{kg}^{-1}$ of body weight. Milt gotten from the selected male was mixed with collected eggs of injected females after the expiration of latency period. 1/3 of the eggs collected from T1 (first female brood stock) and T2 (second female brood stock) were combined and recorded as T3 (mixture of 1/3 of T1 and T2). Each of T1, T2 and T3 were replicated as $\mathrm{T} 11, \mathrm{~T} 12, \mathrm{~T} 13, \mathrm{~T} 21, \mathrm{~T} 22, \mathrm{~T} 23, \mathrm{~T} 31, \mathrm{~T} 32, \mathrm{~T} 33$. Each of the replicated fertilized egg was spread in a monolayer pattern on a $1 \mathrm{~mm}$ diameter net in nine $0.8 \mathrm{~m} \times 0.8 \mathrm{~m} \times 0.8 \mathrm{~m}$ aquarium tank under a recirculatory system. Water quality, fecundity, fertilization rate and survivability of fish were determined. The data collected were analyzed using analysis of variance (ANOVA) at $p<0.05$ significant level.

The percentage fertilization was $62.34^{\mathrm{a}}, 61.98^{\mathrm{a}}$ and $62.75^{\mathrm{a}}$ for $\mathrm{T} 1, \mathrm{~T} 2$ and $\mathrm{T} 3$ respectively. The percentage hatchability was $52.11^{\mathrm{a}}, 50.32^{\mathrm{a}}$ and $51.51^{\mathrm{a}}$ for $\mathrm{T} 1, \mathrm{~T} 2$ and $\mathrm{T} 3$ respectively. The survivability result shows relatively high survival rate in treatment $\mathrm{T} 1$ and $\mathrm{T} 2$, while the rate of survival in T3 was very low.

Egg combination does not have effect on fertilization rate and hatchability of eggs; however, it reduces the survival of larvae. In order to increase survival of catfish fry, it is important to avoid mixture of eggs from multiple brood fish.
\end{abstract}

Keywords: Aquaculture; Fish breeding; Artificial insemination; Catfish

\section{Introduction}

World aquaculture has grown tremendously during the past two decades to becoming an economically important industry [1]. According to [2], aquaculture continues to grow more rapidly than all other animal food-producing sectors, with an average global annual growth rate of $8.8 \%$ per year since 1970 , compared to only $1.2 \%$ for capture fisheries. Globally, aquaculture is expanding into two new directions, intensifying and diversifying. Intensive fish culture has the capacity to produce large quantity of fish per unit space but seldom exists without an efficient fish seed production [3]. Fish seed production is an important aspect of aquaculture that has witnessed continuous research and innovation for increased fish production. Artificial propagation methods constitute the major practicable means of providing enough quality seed for rearing in confined fish enclosure waters such a fish ponds, reservoirs and lakes [4]. Catfish fish seed production is not left out as it represents a valuable fish species most especially in Africa. This fish exhibit a seasonal gonadal maturation which is frequently triggered by rainy season. The maturation processes of C. gariepinus in nature are generally influenced by annual changes in water temperature and photoperiodicity and the final triggering of spawning is usually caused by rise in water level due to rainfall [5]. In captivity, catfish does not spawn by itself, except the environment is simulated to mimic its natural habitat which is a cumbersome process and un-economical. Meanwhile, in its natural environment, several studies have reported poor hatchling and survival performance; [5] reported an average rate of $59.1 \%$ in the rainy season for C. gariepinus in the Republic of Congo, while [6] reported a rate as low as $4 \%$ for C. gariepinus eggs incubated on a nylon substrate. As a result of this, several research has been conducted to improve hatchability and survival of catfish larvae in captivity, among the research are the work of [7] on reproduction growth, health control and aquaculture potential of African catfish Clarias gariepinus; [8] on the effect of various doses of ovaprim on reproductive performance of African Catfish Clarias gariepinus (Bruchell) and Heterobranchus longifilis (Valenciennes); [9] on recent advances in fish hatchery management; [10] on homestead artificial propagation, growth and morphometric characteristics of the African catfish (Clarias gariepinus). Despite all these researches, there still exist a wide gap between fish seed demand and supply. However, the insufficiency of supply and relatively high cost of fingerlings of Clarias gariepinus [11], resulting from low output per breeding attempt, indicates the need to widen the scope of factors affecting the low output. As a result of this backdrop, this project is aimed to study the effects of catfish (Clarias gariepinus) brood-stocks' egg combination on hatchability and survival of fish larvae.

\section{Materials and Methods}

\section{Brood-stock selection and management}

Eight samples, (4 males and 4 females) gravid Clarias gariepinus

*Corresponding author: Onada Olawale Ahmed, University of Ibadan, Nigeria, Tel: +234-000-00-0000; E-mail: onadaolawale@gmail.com

Received December 26, 2016; Accepted January 19, 2017; Published January 21, 2017

Citation: Onada OA, Ogunola OS (2017) Effects of Catfish (Clarias gariepinus) Brood-stocks Egg Combination on Hatchability and Survival of Fish Larvae. J Aquac Res Development S2: 014. doi:10.4172/2155-9546.S2-014

Copyright: (c) 2017 Onada OA, et al. This is an open-access article distributed under the terms of the Creative Commons Attribution License, which permits unrestricted use, distribution, and reproduction in any medium, provided the original author and source are credited. 
brood stock size ranging from $800-900$ g total body weight (TBW) were gotten from the brood-stock tank of the Universite Africaine De Technologie Et De Management, UATM, Benin Republic. This is done after examination for gonad development according to the method of [12]. Male brood-stocks were examined for rigid and reddish infusion of the genital papillae and female genital orifice were examined for reddish infusion, distension of the belly and release of eggs when gentle pressure was applied on the abdomen. Before stocking, the brood fish was disinfected with $0.5 \%$ salt bath $5 \mathrm{~g} \mathrm{NaCl} / 1$ litre water temperature of $25^{\circ} \mathrm{C}$ to $28^{\circ} \mathrm{C}$ according to the method of [13]. Bathing was done by dipping the fish into the solution for fifteen minutes. They were later acclimatized for 2 weeks in holding indoor fibre glass of $1000 \mathrm{~L}$ water holding capacity and maintained under optimum temperature.

\section{Hypophysation of brood-stock}

Two brood-stocks were selected from the pre-selected sample. They were weighed individually and intramuscular injection with pituitary gland hormone earlier extracted from catfish was applied at dosage of 3 $\mathrm{mg} \mathrm{kg}^{-1}$ of body weight [14]. During injection, fish receives finger rubs to prevent back flow of fluid. Once they were injected, each treatment fish were labelled $\mathrm{T} 1$ and $\mathrm{T} 2$ and was kept in different water holding tanks for 14-16 hours in the hatchery.

\section{Fertilization and spreading of eggs on hapa}

The male was sacrificed to obtain the gonads which house the milt. At the expiration of the latency period, the females were carefully removed, moped with towel and hand stripped manually for eggs. Slight pressure was applied on the abdomen of the female brooder, and this led to the ovulated eggs to ooze out easily from the genital opening which was collected in plastic bowl. A sample of 20 unfertilized eggs from each female size class was taken to determine egg sizes. The eggs obtained from stripping each brood-stock were weighed, followed by several drop of creamy milt squeezed over the eggs with dry hands. The bowl is then gently swirled to mix the eggs and milt, feather is also used to mixed egg and milt together so as to ensure that the milt mix properly. $0.9 \%(\mathrm{NaCl})$ saline solution [15] was added to facilitate fertilization. After 45 seconds to one minute, no further fertilization can take place as the sperms are no longer motile. 1/3 of the eggs collected from T1 and T2 were combined and recorded as T3. Each of T1, T2 and T3 where then divided into three equal part as replicate for the three treatment. This was labelled T11, T12, T13, T21, T22, T23, T31, T32, T33. Each of the replicated fertilised egg was spread in a monolayer pattern on a $1 \mathrm{~mm}$ diameter net in nine $0.8 \mathrm{~m} \times 0.8 \mathrm{~m} \times 0.8 \mathrm{~m}$ aquarium tank under a recirculatory system (Table 1 ).

\section{Fertility rate and hatchability rate}

After a certain period of incubation before hatching sub samples of eggs (1gm) kept on separate net were examined to assess the fertility rate (\%) and hatchability rate (\%) as determined from counting the number of active larvae. Prior to hatching, three sample plots were determined on the screen, and the number of fertilized and unfertilized eggs was counted physically for each treatments. The fertilized eggs were green, transparent and flattened whereas the unfertilized ones were whitish in color and thick. The FR\% was computed based on the formula [16].

\begin{tabular}{|c|c|c|}
\hline T1 & T2 & T3 \\
\hline T11 & T21 & T31 \\
\hline T12 & T22 & T32 \\
\hline T13 & T23 & T33 \\
\hline
\end{tabular}

Table 1: Treatment T1, T2 and T3 with their replicate.

\begin{tabular}{|c|c|}
\hline Chemical and physical features & Desired Level \\
\hline Dissolved Oxygen (DO) & $6 \mathrm{mgL}^{-1}$ \\
\hline Water $\mathrm{pH}$ & $7-7.5$ \\
\hline Temperature & $27^{\circ} \mathrm{C}-30^{\circ} \mathrm{C}$ \\
\hline Ammonium $\left(\mathrm{NH}_{4}\right)$ & $0.5 \mathrm{mg} \mathrm{L}$ \\
\hline
\end{tabular}

Table 2: Water quality requirements of african catfish hatchery.

\begin{tabular}{|c|c|c|c|}
\hline \multirow{2}{*}{$\begin{array}{c}\text { Water Quality } \\
\text { Parameters }\end{array}$} & T1 & T2 & T3 \\
\cline { 2 - 4 } & $28.35 \pm 0.10$ & $28.21 \pm 0.07$ & $28.11 \pm 0.06$ \\
\hline Temperature $\left({ }^{\circ} \mathrm{C}\right)$ & $5.29 \pm 0.08$ & $5.28 \pm 0.09$ & $5.28 \pm 0.05$ \\
\hline Dissolved Oxygen $(\mathrm{mg} / \mathrm{L})$ & $7.34 \pm 0.17$ & $7.44 \pm 0.19$ & $7.34 \pm 0.09$ \\
\hline $\mathrm{pH}$ & $0.4 \pm 0.04$ & $0.4 \pm 0.06$ & $0.3 \pm 0.10$ \\
\hline Ammonia $(\mathrm{mg} / \mathrm{L})$ &
\end{tabular}

Table 3: Measured water quality parameters.

$F R \%=\frac{\text { No. of fertilized eggs } \times 100}{\text { Total No. of ova collected }}$

The hatchability rate was calculated as described [8]

$$
H R \%=\frac{\text { No. of hatched eggs } \times 100}{\text { Total No. of eggs incubated }}
$$

\section{Survival rate}

Survivability evaluation was observed for a period of about 1-5 weeks. The post-hatching survivability was evaluated as described by [17] as adopted by [18].

$$
\% \text { Survival }=\frac{(\text { Total no. of larvae }- \text { No. of dead larvae }) \times 100 \%}{\text { Total no. of larvae }}
$$

\section{Water quality determination}

The water quality of the system of culture was monitored daily, parameters like $\mathrm{pH}$, Dissolved Oxygen (DO), Nitrite and temperature was measured during the trials using $\mathrm{HATCH}$ analysis water testing kit model FF-1A following method described by [19], the analysis were done immediately after water samples collection [20] (Table 2).

\section{Data analysis}

The data collected was subjected to standard statistical analysis. The data collected were analyzed using analysis of variance (ANOVA) to find a level of significance at $\mathrm{p}<0.05$. Standard deviation and standard error of mean was calculated per treatment. Also Duncan Multiple Range Test was used for mean separation.

\section{Results and Discussion}

\section{Water quality parameters}

During the study period water qualities parameters were measured and the result is presented in the Table 3 below:

\section{Temperature}

The average temperature taken shows that there is no significant difference between the values recorded for the different treatment. The temperature for the treatment are $\mathrm{T} 1(28.35 \pm 0.10)$; $\mathrm{T} 2(28.21 \pm 0.07)$ and T3 $(28.11 \pm 0.06)$. The mean temperature recorded falls within the ranges recorded by [21] and ranges earlier documented by [19] for optimum performance of freshwaters fish (Figure 1).

\section{Dissolved oxygen}

The dissolved oxygen (DO) concentration measured was with 


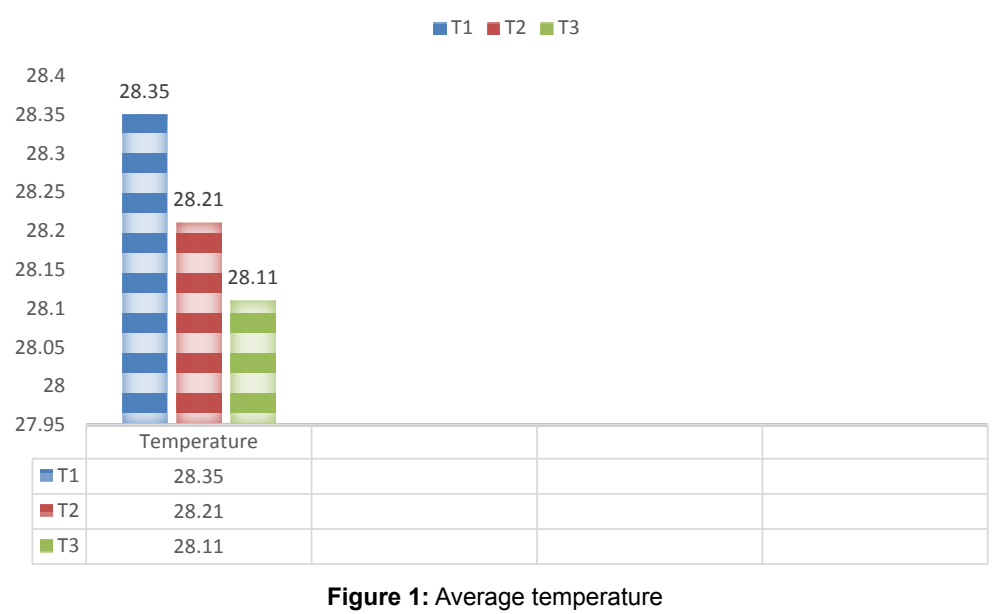

AVERAGE DISSOLVED OXYGEN

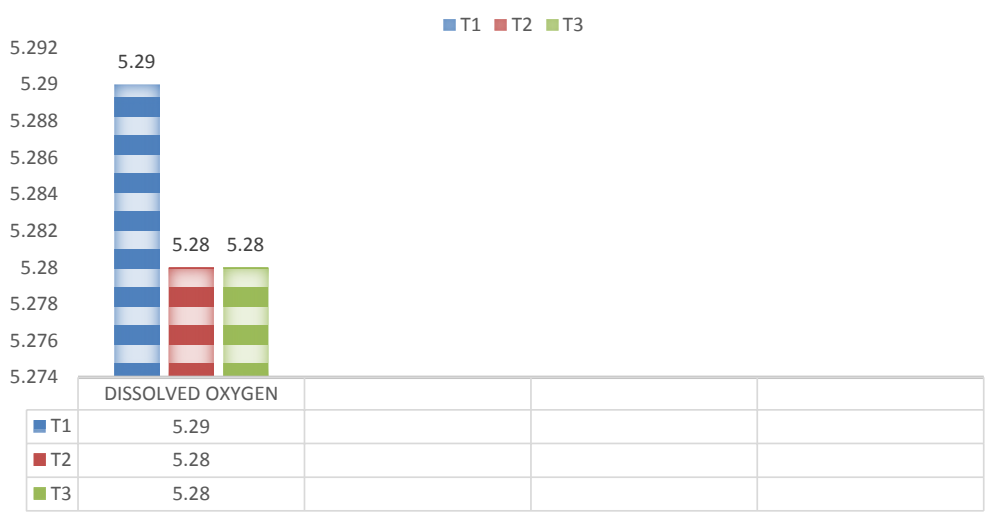

Figure 2: Average dissolved oxygen.

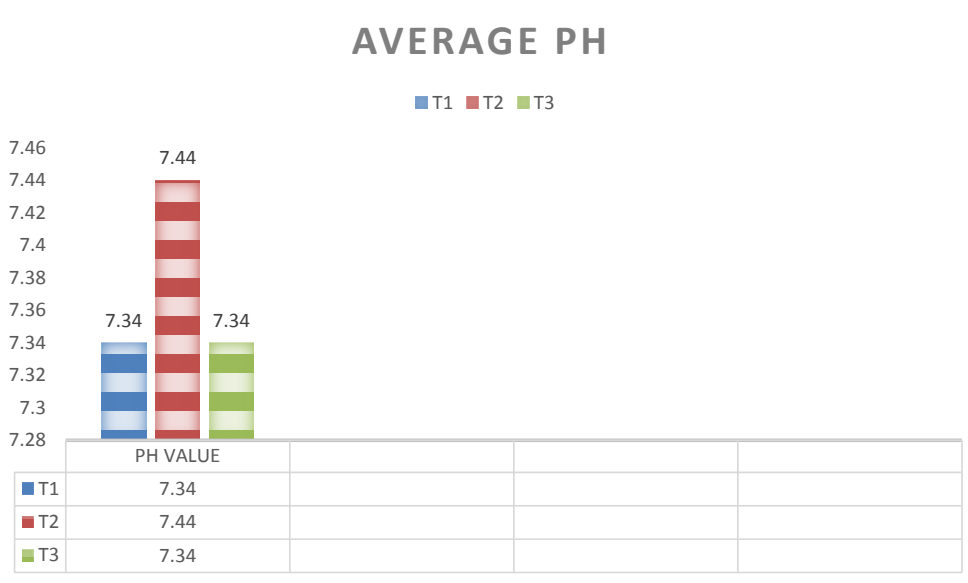

Figure 3: Average $\mathrm{pH}$.

mean value of $5.29 \pm 0.08 ; 5.28 \pm 0.09$ and $5.28 \pm 0.05$ for T1, T2 and T3 respectively. There was no significant difference $(\mathrm{p}>0.05)$ in dissolved oxygen concentration among all treatments during the study periods. The range oxygen recorded in this study slightly varies but fell within the recommended values. These values agree with those of [22], they also pointed out that the minimum dissolved oxygen should be $5 \mathrm{mg} / \mathrm{l}$ for tropical fish (Figure 2).

\section{pH value}

The $\mathrm{pH}$ concentration measured was with mean value of $7.34 \pm$ $0.17 ; 7.44 \pm 0.19$ and $7.34 \pm 0.09$ for $\mathrm{T} 1, \mathrm{~T} 2$ and $\mathrm{T} 3$ respectively. There was no significant difference ( $\mathrm{p}>0.05)$ in $\mathrm{pH}$ concentration among all treatments during the study periods. The range $\mathrm{pH}$ recorded in this study was slightly varies but fell within the recommended values. The 


\section{AMMONIA VALUE}

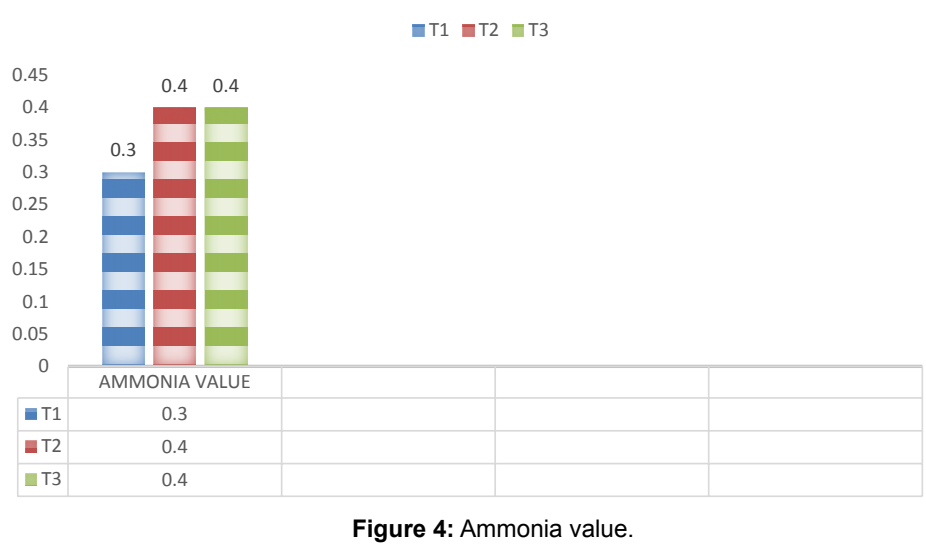

\begin{tabular}{|c|c|c|c|c|}
\hline Parameters & T1 & T2 & T3 & S.E \\
\hline Fecundity & $235,345^{\mathrm{a}}$ & $222,549^{\mathrm{a}}$ & & 5436 \\
\hline \% Fertilization & $62.34^{\mathrm{a}}$ & $61.98^{\mathrm{a}}$ & $62.75^{\mathrm{a}}$ & 1.76 \\
\hline \% Hatchability & $52.11^{\mathrm{a}}$ & $50.32^{\mathrm{a}}$ & $51.51^{\mathrm{a}}$ & 1.55 \\
\hline
\end{tabular}

Values carrying different superscript on the same row differed significantly from each other.

Table 4: Mean fecundity, percentage fertilization and percentage hatchability.

\begin{tabular}{|c|c|c|c|c|c|c|c|c|c|c|c|c|}
\hline \multirow{3}{*}{ Period } & \multicolumn{12}{|c|}{ Initial Stock per Tank is $\mathbf{3 0 0}$} \\
\hline & \multicolumn{3}{|c|}{ Mortality } & \multicolumn{3}{|c|}{$\%$ C.M } & \multicolumn{3}{|c|}{ Survival } & \multicolumn{3}{|c|}{$\%$ C.S } \\
\hline & T1 & T2 & T3 & T1 & T2 & T3 & T1 & T2 & T3 & T1 & T2 & T3 \\
\hline 1 & 5 & 6 & 27 & 1.6 & 2 & 9 & 295 & 294 & 273 & 98.3 & 98 & 91 \\
\hline 2 & 17 & 14 & 87 & 5.6 & 4.7 & 29 & 283 & 286 & 213 & 94.3 & 95.3 & 71 \\
\hline 3 & 25 & 20 & 154 & 8.3 & 6.7 & 51.3 & 275 & 280 & 146 & 91.7 & 93.3 & 49.7 \\
\hline 4 & 32 & 28 & 201 & 10.7 & 9.3 & 67 & 268 & 272 & 91 & 89.3 & 90.7 & 30.3 \\
\hline 5 & 44 & 38 & 289 & 14.6 & 12.7 & 96.3 & 256 & 262 & 11 & 85.3 & 87.3 & 2.7 \\
\hline
\end{tabular}

Table 5: Survivability of hatchlings.

desirable range for pond $\mathrm{pH}$ is 6.5-9.5 and acceptable range is 5.5-10.0 [23]. The range of the $\mathrm{pH}$ obtained from this study was (6.89-7.10), this agreed with [23] (Figure 3).

\section{Ammonia}

The Un-ionized ammonia concentration measured was with mean value of $0.4 \pm 0.04 ; 0.4 \pm 0.06$ and $0.3 \pm 0.10$ for $\mathrm{T} 1, \mathrm{~T} 2$ and $\mathrm{T} 3$ respectively. There was no significant difference $(\mathrm{p}>0.05)$ in Unionized ammonia concentration among all treatments during the study periods. The range Un-ionized ammonia recorded in this study was slightly varies but fell within the recommended values. The ammonia concentration recorded falls within desirable limit $0-0.05 \mathrm{mg} / \mathrm{l}$ and acceptable limit less than $0.5 \mathrm{mg} / \mathrm{l}$ [24] (Figure 4).

\section{Fecundity}

The fecundity of brood stock used during the experiment shows that no significant difference between the two treatments as T1 has fecundity of $235,345^{\mathrm{a}}$ while T2 has $222,549^{\mathrm{a}}$ as presented in Table 3. This must have been as a result of close weight range of the brood stock used in the experiment or probably a coincidence. As several results have shown variation in fecundity of brood stock, although variation in fecundity within a common trail of similar-sized fish species could be attributed to hormone administration rate, breeding history, maturity stage, and other external environmental factors [25].

\section{Percentage fertilization}

The results of the experiment show no significant difference in the percentage fertilization recorded as presented in Table 3. The percentage fertilization was $62.34^{\mathrm{a}}, 61.98^{\mathrm{a}}$, and $62.75^{\mathrm{a}}$ for T1, T2 and T3 respectively.

\section{Percentage hatchability}

The results of the experiment show no significant difference in the percentage hatchability recorded as presented in Table 3 . The percentage hatchability was $52.11^{\mathrm{a}}, 50.32^{\mathrm{a}}$ and $51.51^{\mathrm{a}}$ for $\mathrm{T} 1, \mathrm{~T} 2$ and $\mathrm{T} 3$ respectively.

\section{Survivability}

The survivability result presented in Table 4 shows relatively high survival rate in treatment $\mathrm{T} 1$ and $\mathrm{T} 2$, while the rate of survival in $\mathrm{T} 3 \mathrm{was}$ very low. At the end of the $5^{\text {th }}$ week the survival percentage were $85.3 \%$, $87.3 \%$ and $2.7 \%$ for $\mathrm{T} 1, \mathrm{~T} 2$ and $\mathrm{T} 3$ respectively. The lower survival of T3 as observed in the experiment was due to the development of some fast growing population in the stock. The fast growing population was observed to cannibalize on the slower growing population thereby suppressing their population (Table 5).

\section{Conclusion and Recommendations}

Physical observation during the study confirm two developmental stage of fish after the $3^{\text {rd }}$ day, some population were actively and vigorously seeking to feed, while some population have not fully absorbed their yolk. This could be linked with the combination of eggs from different brood-stock; this made some population or strain to develop faster than the other. Possibility will arise that the difference in developmental stages increases with the increase in the number of female brood fish used. From day 7 to 14 cannibalism surfaced: attacks between different sizes of fish occurred, where the weaker and the slow growing one were seriously affected. The mostly attacked parts are tails, mostly broken with body wounds, eventually dead. Combination of eggs from different female brood fish could hamper the chances of survival. It is however important to strip female eggs separately to have a good survival result.

\section{References}

1. Subasinghe R, Soto D, Jia J (2009) Global aquaculture and its role in sustainable development. Reviews in Aquacul 1: 2-9. 
Citation: Onada OA, Ogunola OS (2017) Effects of Catfish (Clarias gariepinus) Brood-stocks Egg Combination on Hatchability and Survival of Fish Larvae. J Aquac Res Development S2: 014. doi:10.4172/2155-9546.S2-014

Page 5 of 5

2. FAO (2007) The state of world fisheries and aquaculture 2006. FAO fisheries and aquaculture department. Food and Agriculture Organization of the United Nations Rome.

3. Adekoya BB, Olunuga OA, Ayansanwo TO, Omoyinmi GAK (2004) Hand book on Manual of the second annual Fish seminar and training workshop held at Ogun State Agricultural Development Programme (OGADEP), Abeokuta Published by Fisheries Society of Nigeria (FISON), Ogun state chapter.

4. Charo H, Oirere W (2000) River based artificial propagation of the African Catfish, Clarias gariepinus: An option for the small fish farmers. NAGA- The ICLARM Q 2: 14-16.

5. de Graaf GJ, Galemoni F, Banzoussi B (1995) The artificial reproduction and fingerling production of the African catfish Clarias gariepinus (Burchell 1822) in protected and unprotected ponds. Aquaculture Research 26: 233-242.

6. Macharia SK, Ngugi CC, Rasowo J (2005) Comparative Study of hatching rates of African Catfish (Clarias gariepinus Burchell 1822) eggs on different substrates. NAGA, World Fish Center Quaterly 28: 23-26.

7. Huisman EA, Ritcher CJ (1987) Reproduction, growth, health controls and aquaculture potential of the African mud catfish, Clarias gariepinus (Burchell, 1822). Aqua 63: 1-14.

8. Olubiyi OA, Ayinia OA, Ayinia OA, Adeyemo AA (2005) The effects of varying dose of ovaprim on reproductive performance of the African Catfish Clarias gariepinus and Heterobranchus longifilis. Afr J Applied Zool Environ Biol 7: 101-105

9. Phelps RP (2010) Recent advances in fish hatchery management. Soci Bra de Zoot 7: 95-101.

10. Ude MF, Ugwu LLC, Mgbenka BO (2005) Homestead artificial propagation, growth and morphometric characteristics of the african catfish (Clarias gariepinus, Pisces: Clariidae). An Res Int 2: 377-381.

11. Ofor CO (2007) A comparison of the yield and yield economics of three types of semi- intensive grow out systems, in the production of Heterobranchus longifilis (Teleostei: Clariidae) (Val. 1840), in Southeast Nigeria. Aquaculture 269: 402-413.

12. Blythe WG, Helfrich LA, Libey G (1994) Induced maturation of stripped bass, Morone saxatilis exposed to 6,9 and 12 months photothermal regimes. Journal of World Aquaculture Society 25: 183-192.
13. Tonguthai $K$, Chinabut $S$, Limsuwan $C$, Somsior $T$, Chanratchakool $P$, et al. (1993) Handbook of hybrid catfish. Husbandry and Health. The Aquatic Animal Health Research Institute. Kasetsart University. Jjatujak. Bangkok, Thailand.

14. Hogendoorn $\mathrm{H}$, Vismans MM (1980) Controlled propagation of the African catfish Clarias lazera (C\&V). 11 Artificial reproductions. Aquaculture 21: 39-53.

15. Woynarovich E, Horvath $L$ (1980) The artificial propagation of warm-water fin fishes: A manual for extension. FAO Fish Techn Paper.

16. Hogendoorn H (1979) Controlled propagation of the African catfish, Clarias lazera (C \& V). I. Reproductive biology and field experiments. Aquaculture 17: 323-333.

17. Bargenal TB (1978) Effect of nematode infection on the breeding potentia of Clarias gariepinus. Journal of Agriculture, Forestry and the Social Sciences 8: 141-147.

18. Yisa TA, Tsadu SM, Musa A (2010) Effect of nematode infection on the breeding potential of Clarias gariepinus. Journal of Agriculture, Forestry and the Social Sciences 8: 141-147.

19. Boyd CE, Tucker CS (1998) Pond aquaculture water quality management Norwell, Massachusetts, USA: Kluwer Academic Publishers.

20. FAO (1994) Fishery information, data and statistics service; A strategic assessment of warm water fish farming potential in Africa.

21. King RP (1998) Physico-chemical indices of the fisheries potential of Nigerian rainforest pond. J Aqua Sci 13: 49-54.

22. Saloom ME, Duncan RS (2005) Low dissolved oxygen levels reduce antipredator behaviours of the fresh water Clam Corbicula fluminea. Fresh Water Biol 50: 1233-1238.

23. Stone NM, Thormforde HK (2003) Understanding your fish pond water analysis report. University of Arkansas Co-operative Extension Printing services.

24. DWAMD (1994) Division of water ambient monitoring database. (18thEdn).

25. Ataguba GA, Annune PA, Ogbe FG (2009) Induced breeding and early growth of progeny from crosses between two African clariid fishes, Clarias gariepinus (Burchell) and Heterobranchus longifilis under hatchery conditions. Journal of Applied Biosciences 14: 755-760.
This article was originally published in a special issue, Current and Emerging Diseases/Disorders of Fish in Aquaculture handled by Editor(s). Prof. Patrick T.K. Woo, University of Guelph, Canada; Dr. Kenneth D. Cain, University of Idaho, USA. 